\title{
Population dynamics of Cacopsylla sp. (Hemiptera: Psylloidea: Psyllidae), pest insect of Prunus africana (Rosaceae), medicinal plant species in Cameroon
}

\section{Dzokou Victor Joly*}

Department of Crop Protection (UR_PHYZA), Faculty of Agronomy and Agricultural Sciences, University of Dschang, P.O. Box 222 Dschang, Cameroon

\section{Yana Wenceslas}

Laboratory of Biological Sciences, Faculty of Sciences, University of Bamenda, P. O. Box 39 Bambili, Cameroon

\section{Soufo Laurentine}

Department of Biological Sciences, Faculty of Sciences, University of Maroua, P.O. Box 814 Maroua, Cameroon

\section{Tamesse Joseph Lebel}

Department of Biological Sciences, Higher Teachers' Training College, University of Yaounde I, P.O. Box 47 Yaounde, Cameroon

*Corresponding author. E-mail: dzovijo@yahoo.fr

\begin{abstract}
Prunus africana is threatened in Cameroon by xylophagous and sap-sucking pest as Cacopsylla sp. This last causes deformations of the young leaves and buds and the plant end up losing all its leaves. Effective control of phytophagous pests requires a thorough understanding of their seasonal population dynamics. The objective of this work carried out on 150 young plants of $P$. africana in the nursery in Dschang, was to study the population dynamics of Cacopsylla sp. and the impact of climatic factors on the population. From January 2006 to December 2007, monthly collections of larvae, males and females of Cacopsylla sp. were carried out. The results showed, in 2006, three peaks (March, August and December) and two peaks in 2007 (March and August) with larvae. The fluctuation of males' population showed five peaks with two peaks in 2006 (March and December) and three peaks in 2007 (March, June and December) while in females' population, four peaks with two peaks in 2006 (March and December) and two peaks in 2007 (March and November). The annual numerical variation of Cacopsylla sp. individual is statistically correlated with variation of precipitations and the insolation. The precipitations have a negative effect on the numerical variation of males $(r=-0.430, p<0.0360)$ and females $(r=-0,434, p<0.0336)$ of Cacopsylla sp. The insolation has a positive effect on the numerical variation of males $(r=0.732, p<0.0000002)$, females $(r=0.653, p<0.000523)$ and the total individuals $(r=0.601, p<0.00197)$ of Cacopsylla $s p$. With the larvae, the correlation was negative and non-significant. This work showed that March and December were better indicated to engage the fight against Cacopsylla sp. in Dschang.
\end{abstract}

Keywords: Cacopsylla sp., climatic factors, pest population, Prunus africana, Cameroon

\section{INTRODUCTION}

Cacopsylla Ossiannilsson is a Central-Asian and European species of the genus Cacopsylla (Lauterer, 1999) with over 450 described species (Ouvrard, 2018). For 12 species recorded from Iran, 8 species are recorded on Rosaceae, 2 species on Rhamnaceae and 2 species on Salicaceae (Burckhardt and Lauterer, 1993; Zendedel et al., 2016). Certain species of the Cacopsylla genus are vectors of diseases. C. pruni is the vector of the European stone fruit yellows (ESFY) phytoplasma disease caused by pathogen 'Ca. Phytoplasma prunorum'. This ESFY induces serious

\section{Article Info}

https://doi.org/10.31018/

jans.vi.2256

Received: February 6, 2020

Revised: May 27, 2020

Accepted: June 8, 2020

\section{How to Cite}

Dzokou, V. J. et al. (2020). Population dynamics of Cacopsylla sp. (Hemiptera: Psylloidea: Psyllidae), pest insect of Prunus africana (Rosaceae), medicinal plant species in Cameroon. Journal of Applied and Natural Science, 12(2): 221 - 228 https://doi.org/10.31018/ jans.vi.2256 
Messi, 2004); Pseudophacopteron spp., psyllid of Dacryodes edulis (Mapon et al., 2014); Diclidophlebia eastopi and Diclidophlebia harrisoni, psyllid of Triplochiton sclerxylon (Noubissi et al., 2014); Blastopsylla occidentalis, psyllid of Eucalypts (Soufo and Tamesse, 2015); Phytolyma fusca, psyllid of Milicia excelsa (Noubissi et al., 2016). In the camerounian orchards, T. erytreae (Hemiptera: Psylloidea: Triozidae) generates pit galls on the upper face of the attacked leaves during its larval development (Tamesse et al., 1999). Tamesse and Messi (2002) observed that the young seedlings of Citrus were attacked by $T$. erytreae 4 months only after germination. Those plants were stunted, and their leaves greatly deformed. According to the same authors, in the absence of pest management in the citrus nursery, citrus psylla can cause the loss of up to $91 \%$ of young plants. In South Africa, Ethiopia, Rwanda, Burundi, Malawi and Cameroun, this psyllid species is a vector of "greening" or Huanglongbing, a disease of degeneration of citrus fruits (Aubert et al., 1988).

Cacopsylla sp. is a sap-sucking insect of Prunus africana (Rosaceae) in Dschang. It induces deformations of the leaves and buds, as well as necrosis. The survey carried out by Dzokou (2010) notices the presence of another species on Pittosporum viridiflorum (Pittosporaceae) at Lingang, Menoua division. The feeding of the adults and especially of the larvae causes the irreversible rolling up of the leaves of the host plant which lodge at the same time the larvae.

The control of psyllid pests has for many years relied on the use of insecticides, but nowadays, following increasingly severe restrictions concerning the application of chemicals, Integrated Pest Management (IPM) has become the most successful alternative. This was reported by Civolani et al. (2010), Civolani and Pasqualini (2003), Erler (2004) concerning the control of Cacopsylla pyri (pear psyllid). Sanchez and Ortín-Angulo (2012) concluded at the end of their studies on the control of Cacopsylla pyri that natural enemies offer a good opportunity to develop biological and IPM programmes based on conservation of the native fauna in pear orchards in southern Spain. According to Wang (1981), Tsai et al. (2002), Aubert (1987), the three main weather factors influencing the development of Diaphorina citri populations are temperature, relative humidity and rainfall.

$P$. africana is an endemic species of the afromountain forests of Africa and Madagascar. Its ecological milieu generally ranges between 900 and $3000 \mathrm{~m}$ of altitude, in particular, the Highlands of the West, Mount Cameroon, Adamawa, Bakossi mounts and some species domesticate in Centre Region of Cameroon. This species revels an economic, social and scientist importance for the local populations and the international community. Its barks are used in western pharmaceutical industries to look after the benign hypertrophy of the prostate (Tasse, 2006). P. africana is classified by the International Union for the Nature Conservation as a rare and vulnerable species because of continues degradation of its ecosystem related to the strong pressure exerted on the resource and the application of the nondurable methods of harvest. Awono et al. (2015) underline the threats weighing on $P$. africana in the Northwest and South-west regions of Cameroon because of its overexploitation. But the threats due to the pest insects are not signalled by those authors. $P$. africana is in domestication in Cameroon outwards its natural distribution area. But this fact faces threats of the various pests among which one is Cacopsylla sp. It is thus a question of having an idea about the evolution of this pest over different years. The objective of this study was to search the strong pullulating periods of the pest populations and the climatic factors which regulate them over the years for a better control strategy.

\section{MATERIALS AND METHODS}

From 2006 to 2007, larvae, males and females of Cacopsylla sp. were collected from 150 young plants of $P$. africana in the nursery in Dschang $\left(10^{\circ} 04^{\prime} \mathrm{N}, 5^{\circ} 26^{\prime} \mathrm{E}, 1385 \mathrm{~m}\right)$. Regular visits of at least once a month were done. Cacopsylla sp. was captured with the aid of an entomological net and a mouth aspirator and introduced in tubes containing $70 \%$ ethanol. The maximum possible of Cacopsylla sp. individuals were collected on the whole young $P$. africana. In the laboratory, they were sorted into larvae, adult males and females and counted under a binocular lens. Insects are preserved in $70 \%$ ethanol at the Laboratory of Zoology of the University of Yaounde I (LZUY) and the Research Unit of Phytopathology and Agricultural Zoology (UR PHYZA), Laboratory of Agricultural Zoology of the University of Dschang (LAZUDs). Two males, 2 females and 2 larvae from the same collection were deposited in the Naturhistorisches Museum Basel, Switzerland (NHMB). Data was collected on the population dynamics by recording the number of each stage, the number of generations and their peak periods. Based on earlier studies carried out in Austral Africa, population peaks were clearly separated by about 28 days, which corresponds to separate generations. Meteorological data (Table 1) of the years 2006 and 2007 of the study site were obtained from the Institute of Agricultural Research for Development (IRAD), Dschang. The software SPSS version 16.0 was used to analyse the results. The correlation test of Spearman was used to appreciate the numeric variations of different pest stages. Excel program was used to produce diagrams. 


\section{RESULTS}

Faunistic and population dynamics of Cacopsylla sp.: The 24 monthly visits at Dschang, the psyllids were regularly met, corresponding to a frequency of $100 \%$; with 426 individuals (145 males, 139 females, 142 larvae). Cacopsylla sp. (Fig. 1) was a very frequent species known in Menoua Division.

Cacopsylla sp., psyllid of Prunus africana (Rosaceae). Dschang: 13 January 2006, $4 \hat{\delta}, 8$ ㅇ, 2 larvae ; 4 February 2006, 2 o, 4 ㅇ, 2 larvae ; 9 March 2006, 16 ๙, 25 ㅇ, 18 larvae; 23 April

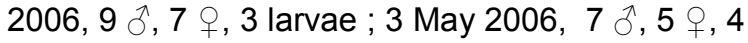
larvae ; 22 June 2006, 7 ๙, 7 \%, 1 larva ; 9 July 2006, 3 ๙, 2 , 4 larvae ; 2 August 2006, 4 ก, 1 +, 7 larvae ; 27 September 2006, 2 , 6 larvae ; 23 October 2006, 1 §, 1 \%, 2 larvae ; 25 November 2006, 8 ग, 5 ㅇ, 1 larva ; 3 December 2006, 23

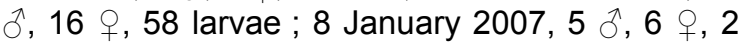
larvae ; 8 February 2007, 3 ग, 2 q ; 17 March
2007, 9 ๙, 7 , , 6 larvae ; 10 April 2007, 6 ภ, 5 , 2 larvae ; 17 May 2007, 5 o, 5 , 2 larvae ; 27 June 2007, 6 ๙, 4 , , 1 larva ; 10 July 2007, 3 ๙, 5 , 5 larvae ; 15 August 2007, 2 ก, 2 , 6 larvae ; 21 September 2007, 3 o, 4 ㅇ, 2 larvae ; 11 October 2007, 3 ऽ, 3 \%, 1 larva ; 8 November 2007, 7 ภ, 7 , 2 larvae ; 21 December 2007, 9 ภ, 6 , 5 larvae.

The first peaks were observed in March 2006, two months only after the beginning of the rains. In March, the rains were average, whereas in December, the rains were null and the insolation maximal. Also, the largest peak of females was located in March 2006. The lifting of dormancy of the buds began with the arrival of rains. The second peak of the adults was observed in December 2006, in the high dry season. Indeed, there were no rains in December 2006 and January 2007 in Dschang (Fig. 2).

Ombrothermic diagram of Dschang (2006 and 2007): From the diagram (Fig. 3), we had 6

Table 1. Meteorological data of Dschang years 2006-2007 obtained from the Institute of Agricultural Research for Development (IRAD).

\begin{tabular}{llllllllllllll}
\hline $\begin{array}{l}\text { Factors \& } \\
\text { Years }\end{array}$ & \multicolumn{3}{c}{$\begin{array}{c}\text { Temperature } \\
\left({ }^{\circ} \mathbf{C}\right)\end{array}$} & \multicolumn{3}{c}{ Precipitations (mm) } & \multicolumn{3}{c}{ Insolation (H 1/10) } & \multicolumn{2}{c}{$\begin{array}{c}\text { Wind speed } \\
(\mathbf{m} / \mathbf{s})\end{array}$} \\
\cline { 2 - 6 } & $\mathbf{2 0 0 6}$ & $\mathbf{2 0 0 7}$ & $\mathbf{2 0 0 6}$ & & $\mathbf{2 0 0 7}$ & & $\mathbf{2 0 0 6}$ & $\mathbf{2 0 0 7}$ & $\mathbf{2 0 0 6}$ & $\mathbf{2 0 0 7}$ \\
\hline Months & Mean & Mean & Qt & ND & Qt & ND & Qt & ND & Qt & ND & Qt & ND \\
January & 21.5 & 20.25 & 19.9 & 02 & 00 & 0 & 129.2 & 28 & 224.7 & 31 & 886.7 & 1313.9 \\
February & 21.85 & 21.75 & 90.2 & 08 & 15.2 & 02 & 61.9 & 24 & 124.2 & 26 & 687.4 & 930.4 \\
March & 22.2 & 22.6 & 174.2 & 14 & 74.4 & 08 & 129.2 & 24 & 142.7 & 30 & 899.6 & 1331.4 \\
April & 21.75 & 21.55 & 108.3 & 13 & 181.7 & 22 & 134.4 & 28 & 139.5 & 29 & 850.1 & 1061.8 \\
May & 20.6 & 21.25 & 279.8 & 25 & 167.7 & 16 & 124.8 & 28 & 187.3 & 29 & 741.0 & 1304.5 \\
June & 20.9 & 20.9 & 210.5 & 14 & 233.3 & 20 & 130.4 & 27 & 136.9 & 29 & 733.9 & 673.9 \\
July & 20.25 & 19.95 & 240.2 & 24 & 249.6 & 22 & 85.5 & 29 & 98.0 & 28 & 738.6 & 567.5 \\
August & 20.25 & 19.65 & 177.6 & 22 & 248.2 & 24 & 72.5 & 24 & 62.5 & 26 & 531.5 & 633.1 \\
September & 20.7 & 20 & 305.9 & 26 & 319.0 & 25 & 74.6 & 26 & 90.1 & 28 & 716.0 & 857.4 \\
October & 20.85 & 20.3 & 116.2 & 22 & 148.6 & 25 & 81.2 & 27 & 134.0 & 30 & 1264.8 & 1795.0 \\
November & 20.45 & 20.25 & 24.6 & 07 & 86.7 & 12 & 175.8 & 30 & 163.0 & 27 & 1174.4 & 1453.5 \\
December & 20.2 & 19.6 & 0.0 & 0 & 0.8 & 01 & 218.5 & 30 & 203.1 & 31 & 967.2 & 1890.1 \\
\hline
\end{tabular}

Qt: Quantity, ND: Number of Days

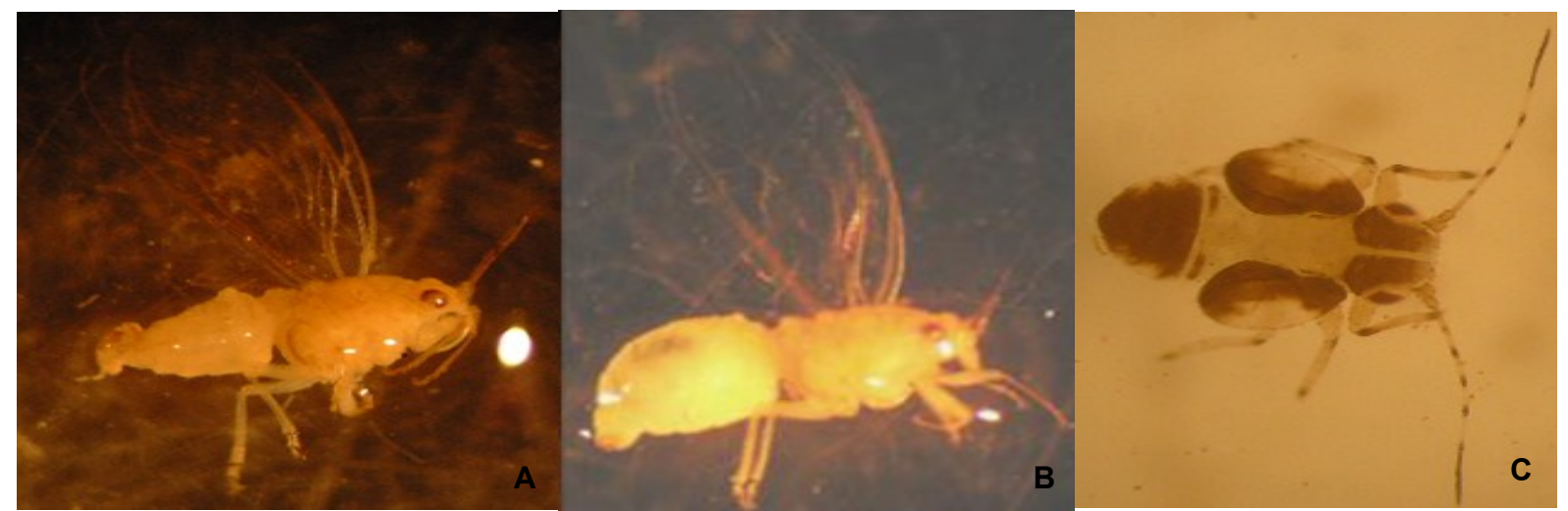

Fig. 1: Cacopsylla sp., A: male; B: female; C: firth instar larva. 


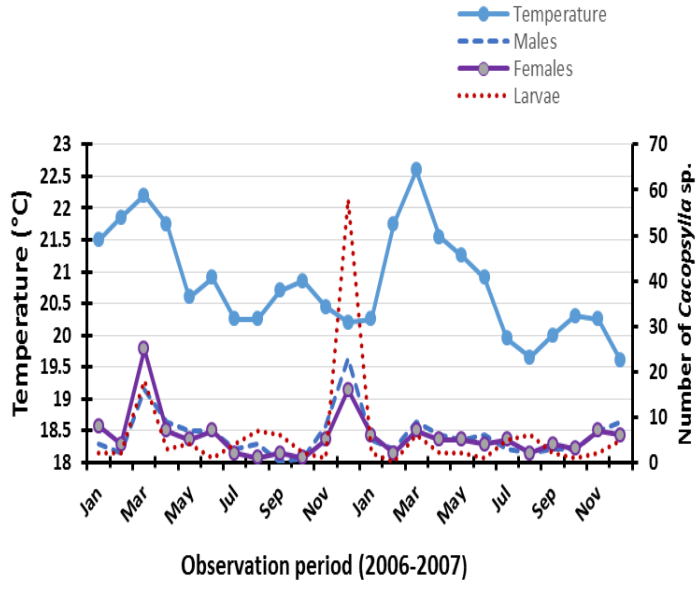

Fig. 2: Abundance of males, females and larvae of Cacopsylla sp. on $P$. africana and the temperature variation in Dschang from January 2006 to December 2007.

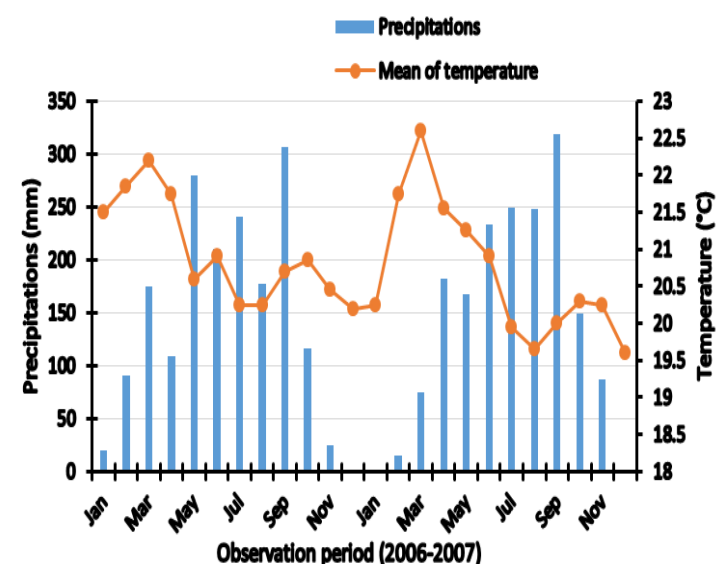

Fig. 3: Ombrothermic diagram of the locality of Dschang (years 2006 and 2007).

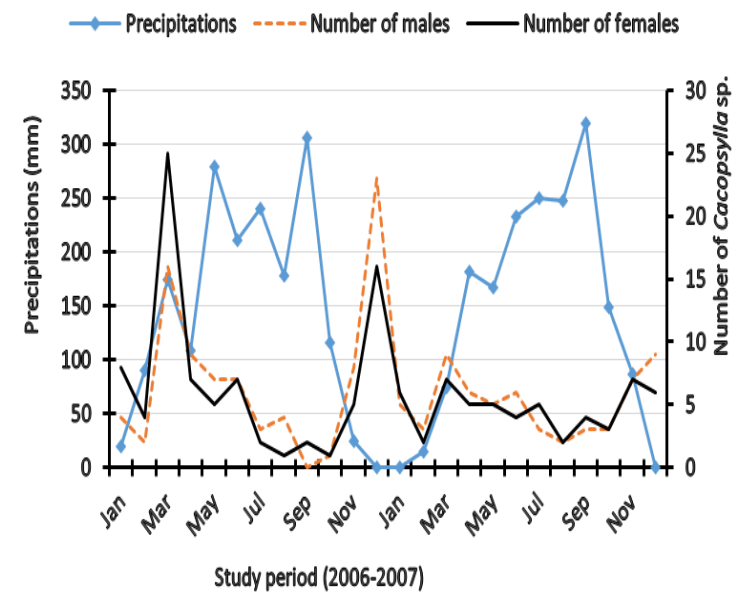

Fig. 4: Abundance of males and females of Cacopsylla sp. on $P$. africana and the precipitations variation in Dschang from January 2006 to December 2007. months of dryness than 3 months per year. It is noticed that dryness is signalled when precipitations are inferior to $50 \mathrm{~mm}$ for a given month. Dryness occurred the months of November, December and January for the year 2006 and December, January and February for the year 2007. The month of September is considered as the month with most precipitations with $305.9 \mathrm{~mm}$ during 26 days in 2006 and $319 \mathrm{~mm}$ during 25 days in 2007 . The months of January and February 2006 were the warmest with respectively $29.2^{\circ} \mathrm{C}$ and $29^{\circ} \mathrm{C}$ while the less warm months were July $\left(25.6^{\circ} \mathrm{C}\right)$ and August $\left(25^{\circ} \mathrm{C}\right)$. As for the year 2007 , the months of February $\left(30.4^{\circ} \mathrm{C}\right)$ and March $\left(30.3^{\circ} \mathrm{C}\right)$ while the less warm months were July and August with $25.1^{\circ} \mathrm{C}$ each.

Wind speed and insolation variation in the locality of Dschang (2006 and 2007): The wind speed data showed that the maximal speed is $1890.1 \mathrm{~m} / \mathrm{s}$ in the month of December 2007 and the minimal speed of $531.5 \mathrm{~m} / \mathrm{s}$ in the month of August 2006. The maximal insolation was observed in the month of January 2007 with a value of $224.7 \mathrm{H} 1 / 10$ during 31 days. The months of February 2006 and August 2007 were the less sunny with respectively $61.9 \mathrm{H} 1 / 10$ during 24 days and $62.5 \mathrm{H} 1 / 10$ during 26 days.

Effects of rainfall on the numerical variations of Cacopsylla sp.: The correlation of Spearman between the numerical individuals variation of different developmental stages of Cacopsylla sp. and the rainfall (Fig. 4) was: $r=-0.430, p=0.0360$ for males; $r=-0.434, p=0.0336$ for females; $r=$ $0.412, p=0.847$ for larvae; $r=-0.369, p=0.0746$ for the total. According to the correlation test (Table 2), correlation coefficient ( $r$ ) was negative and significant with the variation of males and females individuals with the variation of rainfall. The numerical variations of males and females Cacopsylla sp. were correlated with rainfall. This means less abundance precipitation induced the increase of adults individuals of Cacopsylla sp. The correlation coefficient ( $r$ ) was positive and negative, and non-significant for the larvae and the whole individuals, respectively.

Effects of insolation on numerical variations of Cacopsylla sp.: The Spearman correlation test between the numerical variations of the individuals of the different developmental stages of Cacopsylla sp. and insolation (Fig. 5) were: $r=-0.171, p=$ 0.421 for the larvae; $r=0.732, d d=24, p=$ 0.0000002 for the males; $r=0.653, p=0.000523$ for the females; $r=0.601, p=0.00197$ for the whole individuals. According to the correlation test (Table 2), the correlation coefficient ( $r$ ) was negative and non-significant with larvae; positive and very highly significant with males and females; positive and highly significant with the whole individuals of Cacopsylla sp.

Effects of temperature on the numerical variations of Cacopsylla sp.: The Spearman correla- 
Table 2. Spearman correlation test between the developmental stages of Cacopsylla sp. and some climatic parameters in Dschang from January 2006 to December 2007.

\begin{tabular}{|c|c|c|c|c|c|}
\hline \multirow[t]{2}{*}{ Parameters } & & \multicolumn{4}{|c|}{ Developmental stages } \\
\hline & & Larvae & Males & Females & Whole individuals \\
\hline \multirow[t]{2}{*}{ Temperature } & $r$ & -0.104 & 0.239 & 0.324 & 0.138 \\
\hline & $\mathrm{P}$ & 0.626 & 0.257 & 0.121 & 0.515 \\
\hline \multirow[t]{2}{*}{ Rainfall } & $r$ & -0.0412 & -0.430 & -0.434 & -0.369 \\
\hline & $P$ & 0.847 & $0.0360^{*}$ & $0.0336^{*}$ & 0.0746 \\
\hline \multirow[t]{2}{*}{ Insolation } & $r$ & -0.171 & 0.732 & 0.653 & 0.601 \\
\hline & $\mathrm{P}$ & 0.421 & $0.0000002^{* *}$ & $0.000523^{* *}$ & $0.00197^{*}$ \\
\hline \multirow[t]{2}{*}{ wind speed } & $r$ & -0.253 & 0.171 & 0.0721 & 0.0514 \\
\hline & $P$ & 0.230 & 0.419 & 0.734 & 0.809 \\
\hline
\end{tabular}

$\mathrm{P} \leq 0.05, \mathrm{ddl}=24,{ }^{*}=$ significant, ${ }^{* *}=$ very highly significant

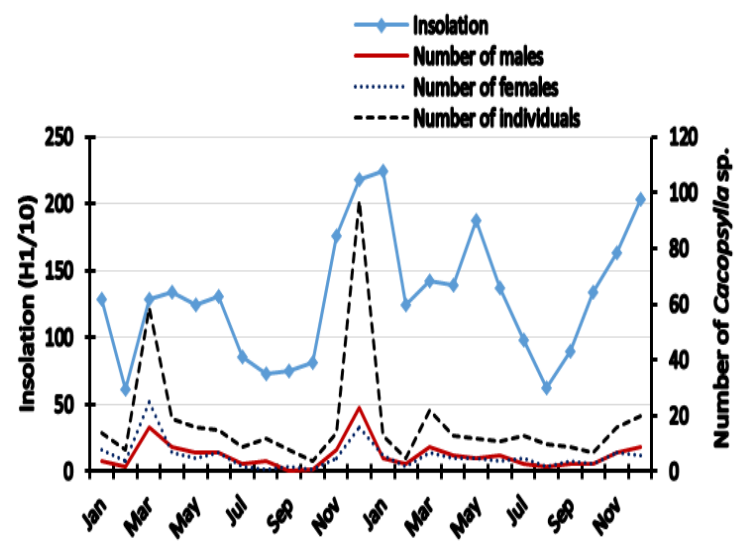

Study period (2006-2007)

Fig. 5: Population dynamics of Cacopsylla sp. on $P$. Africana and the Insolation variation in Dschang from January 2006 to December 2007.

tion test between the numerical variations of individuals of different developmental stages of Cacopsylla $\mathrm{sp}$. and the temperature was: $\mathrm{r}=$ $-0.104, p=0.626$ for larvae (Fig. 6); $r=0.239, p=$ 0.257 for males; $r=0.324, p=0.121$ for females; $r=0.138, p=0.515$ for total individuals. According to the correlation test (Table 2), the correlation coefficient ( $r$ ) was negative and non-significant with the larvae; it was positive and non-significant with the males, females and the whole individuals in our area of study. This meant annual numerical variation of Cacopsylla sp. was not directly linked with the annual variation of temperature.

Effects of wind speed on the numerical variations of Cacopsylla sp.: The Spearman correlation between the numerical variation of individuals of different stages of development of Cacopsylla sp. and the wind speed was: $r=-0.253, p=0.230$ for the larvae; $r=0.171, p=0.419$ for the males; $r$ $=0.0721, p=0.734$ for the females; $r=0.0514, p$ $=0.809$ for the total individuals. According to the correlation test (Table 2), the correlation coeffi-

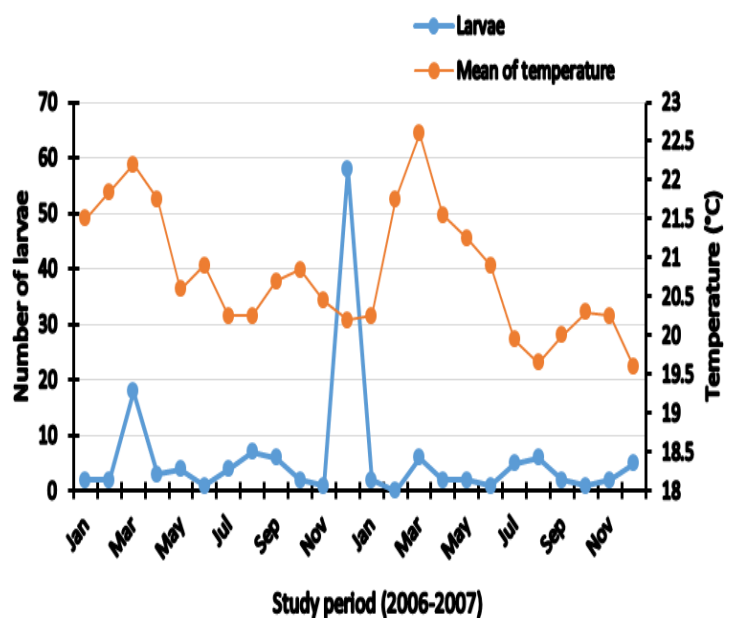

Fig. 6: Abundance of Cacopsylla sp. larvae on $P$. africana and the mean of temperature variation in Dschang from January 2006 to December 2007.

cient $(r)$ was negative and non-significant for larvae. For the males, the females and the total individuals, the correlation coefficient $(r)$ was positive and non-significant. This meant annual numerical variation of Cacopsylla sp. individuals was not directly linked with the annual variation of wind speed.

Impact of damages caused by $P$. africana (Rosaceae): The psyllids attacked the young leaves and buds in the nursery. The leaves lodging the young larvae became deformed while being folded upon their lower faces. These deformations were followed by the drying of the bodies attacked after the last moult of the insects. The larvae produced a white wax which appeared at the end of the anal pore. The damage in the nursery was remarkable since young plants of 3 month-old lodged the adults and the larvae of psyllids.

\section{DISCUSSION}

The numerical fluctuations of the populations of Cacopsylla sp. enabled us to identify in Dschang 
in 2006, 2 annual generations and 2 others in 2007. The presence of young buds and young leaves on $P$. africana would at least partly explain the abundance of the adult stages in March. We noticed that the number of annual generations of psyllid did not vary from one year to another. However, the 2 generations of 2006 had more significant peaks. The results were contrary to the findings of Noubissi et al. (2016) who had indicated that the numbers of the generation of Phytolyma fusca varied from one year to another in Yaounde. The same statement was made by various authors studying the population dynamic of psyllids in the same region (Diclidophlebia eastopi and $D$. harrisoni (Noubissi et al., 2014); B. occidentalis (Soufo and Tamesse, 2014); and Pseudophacopteron spp. (Mapon and Tamesse, 2014). The number of generations of psyllid species varied with the geographical location of the host plant. Cacopsylla sp. presented two annual generations in West region of Cameroon, while in the centre region of Cameroon, the species presented three generations; the first generation appeared in February and disappeared in June, second appeared in June and disappeared in August, while the third appeared on October and disappeared on February (Yana, 2012). The number of generations of psyllid species also can vary with the psyllid species and for a year to another. The number of generations found by Tamesse and Messi (2004) was 8 in 1992 and 3 in 1993 on the citrus psyllid in Yaounde. This can be explained by the fact that climate change affected the stability of climatic factors and the phenology of the host plant, which directly links with the fluctuation of psyllid populations. Aubert (1988) stated that $D$. Citri mortality increased with higher rainfall and relative humidity, but it was very low under hot and dry climates. The numerical variations of males, females and the total individuals were correlated with insolation. The increasing of insolation induced the increase of the number of adults of Cacopsylla sp. in Dschang. The correlation coefficient ( $r$ ) was negative and non-significant with the larvae. This means annual numerical variation of larvae was not directly linked with the annual variation of insolation. From early April in 1999 and 2000, according to Teck et al. (2011), generations of adult and nymph of $D$. citri were increased progressively, and population density increased exponentially as the dry season (April to September) progressed in Sarawak.

The greatest number of larvae was met in December 2006. For the same period, the wind speed was maximum, the temperature and the insolation were average, whereas precipitations were null. Teck et al. (2011) on the seasonal population dynamics of Diaphorina citri (Hemiptera-PsyllidaeDiaphorininae) in Sarawak showed higher populations of larvae during the rainy season than during the dry season but heavy rainfall reduced population of larvae because eggs, first and second instar nymphs, were washed from October 1999January 2000 in Sarawak. This was similar to what we observed with Cacopsylla sp. where heavy rainfall occurred on September 2006 and 2007 in Dschang, and the number of larvae was very low during September. Also advanced larvae stages (L4 to L5), which moved on the organs of the host plant in search of food, would be washed by heavy rainfall. According to De Queiroz et al. (2012), the decrease of Glycapis brimblecombei (Hemiptera-Psyllidae-Spondyliaspidinae) population observed in São Paulo, Brazil at the end of spring, and beginning of summer in 2003, was attributed to the heavy rainfall. Other factors not taken into consideration in this work would control the numerical variation of Cacopsylla sp. larvae in Dschang. Evidently, the presence of parasitoids and predators of Cacopsylla sp. had an impact on its population. The correlation was negative and significant between the adult stages of Cacopsylla sp. and precipitations. This abundance of the adults can be explained by this absence of rains whose presence would impact negatively on the adults of Cacopsylla sp. This is why the adult populations of Cacopsylla sp. were weak between May-September 2006 and Avril-October 2007, which corresponded to the rainiest periods. Also, Tamesse and Messi (2004) showed that the populations of $T$. erytreae were higher between December and March during the great dry season and lowered between September and November during the great rainy season in Yaounde. The coefficient of correlation ( $r$ ) was negative and nonsignificant for the wind speed. The results of the present study showed that there was a correlation between the annual variation of insolation, rainfall and Cacopsylla sp. population variation. This corroborated what was noticed on citrus orchards in Abohar-India for D. citris by Arora et al. (1997), but different than that was observed in Yaounde on $P$. africana by Yana (2012) where no climatic factor was correlated with numerical variation of Cacopsylla sp.

\section{Conclusion}

In Dschang, Cacopsylla sp. populations could colonise and breed on $P$. africana trees throughout the year (2006-2007). During the two years of study, generations with a higher number of individuals were obtained in March and December months. The current study showed that the beginning of the rain season in March favoured increasing adult populations of Cacopsylla sp. through the lifting of dormancy of the buds of $P$. africana. The correlation values from the present studies showed that the insolation and rainfall appeared to have a greater impact on Cacopsylla sp. population than temperature and wind speed. Any biolog- 
Dzokou, V. J. et al. / J. Appl. \& Nat. Sci. 12(2): 221 - 228 (2020)

ical or integrated pest management against this significant pest of $P$. africana in the Western Highlands of Cameroon should take into consideration these periods of strong concentrations of the pest. It is suggested that, in addition to the climatic factors, the physiological state of the trees, the edaphic conditions and the farming care, will allow a better justification of the seasonal variations of the populations of $P$. africana psyllid in Cameroon.

\section{REFERENCES}

1. Arora, P.K., Thind, S. K., Kaur N. and Grewall. S. (1997). Population dynamics of citrus psylla, Diaphorina citri Kuwayama on kinnow mandarin in relation to temperature and relative humidity. Indian J. Ecol. 24: 179-183.

2. Aubert, B. (1988). Towards an integrated management of citrus greening disease. Proceedings of $10^{\text {th }}$ Conference International Organization of Citrus Virologists, (IOCV' 88), pp: 226-230.

3. Aubert, B. (1987). Trioza erytheae del Guercio and Diaphorina citri Kuwayama (Homoptera:Psylloi dea), the two vectors of citrus greening disease: Biological aspects and possible control strategies. Fruits, 42 : 149-162.

4. Aubert, B., Garnier, M., Cassin, J.C. and Bertin, Y. (1988). Citrus greening disease survey in East and West African countries south of Sahara, pp. 231237. In Proceedings of the Tenth Conference of the International Organisation of Citrus Virologists, 1988, Spain (Edited by L.W. Timmer, S.M. Garnsey and S.L. Navarro). University of California Press, CA, USA.

5. Awono, A., Tchindjang, M., Levang, P. (2015). Inventory of fixtures of the barks of Prunus africana: case of the areas of the North-West and the South-West of Cameroon. Scientific and Technical Review Forest and Environment of the Basin of Congo, 6, 46-59. [From French translation].

6. Bodnár, D., Csüllög, K. and Tarcali, G. (2018). Review of the biology of plant psyllid (Cacopsylla pruni, Scopoli 1763), and its role in the spreading of European stone fruit yellows, ESFYphytoplasma with Hungarian data. Acta Agraria Debreceniensis, 74, 25-33. https://doi.org/10.3 4101/actaagrar/74/1660.

7. Burckhardt, D. and Lauterer, P. (1993). The jumping plant-lice of Iran (Homoptera-Psylloidea). Revue Suisse de Zoologie, 100, 829-898.

8. Carraro, L., Ferrini, F., Labonne, G., Ermacora, P. and Loi, N. (2004). Seasonal infectivity of Cacopsylla pruni, vector of European stone fruit yellows phytoplasma. Ann. Appl. Biol. 144: 191195.

9. Civolani, S. and Pasqualini, E. (2003). Cacopsylla pyri L. (Hom.,Psyllidae) and its predators relationship in Italy's Emilia Romagna region. J. Appl. Entomol. 127: 214-220.

10.Civolani, S., Cassanelli, S., Rivi, M., Manicardi, G.C., Peretto, R., Chicca, M., Pasqualini, E. and Leis, M. (2010). Survey of susceptibility to abamectin of pear psylla (Hemiptera: Psyllidae) in northern Italy. J. Econom. Entomol. 103: 816-822.

11.De Queiroz, D.L., Burckhardt, D. and Majer, J. (2012). Integrated Pest Management of Eucalypt
Psyllids (Insecta, Hemiptera, Psylloidea). Chapter . February 2012. DOI: 10.5772/32631 . Source: InTech. https://www.researchgate.net/publication/22 1925827

12.Dzokou, V.J. (2010). Contribution to the study of the psyllids (Hemiptera-Psylloidea) of the West region of Cameroon and taxonomy of Homotomidae HeslopHarrison of Cameroon. Thesis of Doctorat/Ph.D, University of Yaounde I, Cameroon, 201p. [From French translation].

13.Erler, F. (2004). Natural enemies of the pear psylla Cacopsylla pyri in treated vs untreated pear orchards in Antalya, Turkey. Phytoparasitica, 32 295-304.

14. Hodkinson, I. D. (2009): Life cycle variation and adaptation in jumping plant lice (Insecta: Hemiptera: Psylloidea) a global synthesis. Journal of Natural History, 43 : 65-179.

15.Lauterer, P. (1999): Results of investigations on Hemiptera in Moravia, made by Moravian Museum (Psylloidea 2). Acta Musei Moraviae. Science Biologicae (BRNO), 84 : 71-151.

16.Mapon, N.I. and Tamesse, J.L. (2014). Populations dynamic of Pseudophacopteron spp. (Hemiptera: Phacopteronidae), psyllids pest of Dacryodes edulis (Burseraceae) in Cameroon. International Journal of Agronomy and Agricultural Research, 5 (1): 56-73.

17.Noubissi, Y.E., Yana, W. and Tamesse, J.L. (2014). Population dynamic of Diclidophlebia eastopiVondráček and Diclidophlebia harrisoni Osisanya, psyllids pest of Triplochiton scleroxylon (K. Schum) (Urticales: Sterculiaceae) in Yaoundé, Cameroon. Journal of Entomology, 11(4): 182-197.

18.Noubissi, Y.E., Yana, W. and Tamesse, J.L. (2016). Population dynamics of Phytolyma fusca Alibert (Hemiptera: Homotomidae), psyllids pest of Milicia excels (Welw) (Rosales: Moraceae) in Cameroon. Journal of Entomology and Zoology Studies, 4(6) : 256-262.

19.Ouvrard, D. (2018). Psyl' list - The World Psylloidea Database. http://www.hemiptera-databases. com/ psyllist [accessed: 10.09.18], Doi:10.5519/0029634

20.Sanchez, J. A., Ortín-Angulo, M.C. (2012). Abundance and population dynamics of Cacopsylla pyri (Hemiptera: Psyllidae) and its potential natural enemies in pear orchards in southern Spain. Crop Protection, 32 : 24-29.

21.Soufo, L. and Tamesse, J.L. (2015). Population Dynamic of Blastopsylla occidentalis Taylor (Hemiptera: Psyllidae), a Psyllid Pest of Eucalypts. Neotrop. Entomol. 44(5): 504-512. DOI 10.1007/s13744-0150304-7

22.Tamesse, J.L. and Messi, J. (2004). Factors influencing the population dynamics of the African citrus psyllid Trioza erytreae Del Guercio (Hemiptera:Triozidae) in Cameroon. International Journal of Tropical Insect Science, 24(3): 213-227. DOI:10.1079/IJT200429. [From French translation].

23.Tamesse, J.L. and Messi, J. (2002). Incidence of Trioza erytreae (del Guercio) (Homoptera: Triozidae), psyllid vector of Greening on the sensitivity of the citrus fruits seedlings in a nursery in Cameroon. Insect Sci. Applic. 22(2): 97-103. DOI: 10.1017/ S1742758400015174. [From French translation].

24.Tamesse, J.L., Messi, J., Nguyen, T.X. and Quilici, S. (1999). Presence of Trioza erytreae Del Guercio, the psyllid of citrus fruits, in the principal ecoclimatic zones of Cameroon. Fruits, 54 : 311-321. [From 
French translation].

25.Tassé, B.D. (2006). Ecological impact of the exploitation of the bark of Prunus africa (Hook. F.) Kalkman in the area of the Mount Cameroon: Case of the Bokwango-Mapanja zone. Master of Engineer of Water, Forests and Hunting, University of Dschang, Cameroon. 56 p. [From French translation].

26.Teck, S.L.C., Fatimah, A., Beattie, A., Heng, R.K.J. and King, W.S. (2011). Seasonal Population Dynamics of the Asian Citrus Psyllid, Diaphorina citri Kuwayama in Sarawak. American Journal of Agricultural and Biological Sciences, 6(4) : 527-535.

27.Tsai, J.H., Wang, J.J. and Liu, Y.H. (2002). Seasonal abundance of the Asian citrus psyllid, Diaphorina citri (Homoptera: Psyllidae) in Southern Florida. Fla. Entomol., 85: 446-451. DOI: 10.1653/0015-4040(2002)
085[0446: SAOTAC] 2.0.CO;2

28.Wang, C.L. (1981). Ecological studies of Asiatic citrus psyllid (Diaphorina citri K.) with special reference to its spatial distribution. J. Agric. Res. China, 30: 412-419.

29.Yana, W. (2012). Bioecology, Faunistic of psyllids (Hemiptera: Psylloidea) pest of plants in the Center Region and Taxonomy of Ciriacreminae Enderlein 1910 of Cameroon. Thesis of Doctorat/Ph.D, University of Yaounde I, Cameroon, 220p. [From French translation].

30.Zendedel, A., Burckhardt, D., Fekrat, L., Manzari, S. and Sadeghi N.H. (2016). An Annotated checklist of the jumping plant-lice (Hemiptera: Psylloidea) of Iran. Journal of the Entomological Research Society, 18 (1) : 37-55. 